\title{
The Study of the Whole Process of Quality Control of English Graduate Education Based on Quality Control Jing-Wen MA
}

Foreign language department, Shandong Technology and Business University, Yantai Shandong, China, 264005

xssy163@163.com

Keywords: English graduate education; Internal Control; Quality Control System; Control Activities; Risk Assessment

\begin{abstract}
Referring to the methods of enterprise quality guarantee theory and the five elements of the internal control theory, control environment, risk assessment, control activities, information and communication, supervision, from three aspects of teaching, scientific research management, and degree management, the paper establishes the process of quality control of English graduate student training of administration mechanism. In order to safeguard and improve the quality of graduate education, some suggestions are put forward.

With the rapid development of social economy, the demand for senior specialized English talents is growing, and postgraduate education scale is also expanding. With the increase of the number of graduate students, graduate student is diverse, and the quality of graduate education is facing a series of challenges. Under such circumstance, how to evaluate graduate quality, how to guarantee and how to improve the quality of graduate education and how to realize the sustainable development of degree and English graduate student education are the urgent tasks in front of us [1].
\end{abstract}

\section{Internal Control Theory and the Quality Administration of English Graduate Education}

Quality of graduate education is the sign of a university personnel training quality, scientific research level and innovative ability ${ }^{[3]}$. In order to ensure the sustainable, healthy and positive development of the postgraduate education, it is necessary to establish postgraduate education quality guarantee system and incentive mechanism through the reform.

In May 2013, the COSO (The Committee of Sponsoring Organizations of the Tread way Commission) issued updated version of the Internal Control -- Overall Framework. Overall internal control framework is the overall guidance of the current research on internal control framework, and includes control environment, risk assessment, control activities, information and communication and monitoring. The five elements of internal control is the core of the internal control theory, and they coordinate each other and form the internal control system: the control environment is the basis of internal control; risk assessment is the premise of internal control; the control activities are the main part of the internal control; information and communication is the guarantee of internal control and monitoring is the external mechanism of the internal control.

The COSO framework provides an effective way for the construction and development of quality control system of graduate education. Quality control system of graduate education is a complicated system engineering, including recruitment, tutors, determination of cultivation scheme and cultivation years, course teaching, intermediate inspection and thesis opening report, thesis review and thesis defense and many other important links ${ }^{[6] .}$ Therefore, it is possible to borrow the theory of internal control in the whole process control system of graduate education, according to the basic ideas and methods of the internal control theory. The five elements of graduate student training system of controlling system of controlling, risk assessment, control activities, information and communication control system and supervision and incentive system are established to guide the cultivation of English graduate students, eventually achieve the goal of improving the quality of graduate education. 


\section{The Process of the Cultivation of English Graduate Students of Administration Construction Quality Control System Based on the Theory of the Internal Control}

According to the internal control theory, combined with the history and reality of the development of higher education in our country, this paper constructs the quality control system of English graduate education, as shown in figure 1. The system includes: quality management system centered on the training quality management object, namely "manage what"; management rules system directly related to quality, namely "how to manage"; evaluation monitoring system mainly on training quality assessment, namely "how about the management"; and environment supporting system indirectly related to training quality, namely "management atmosphere” ${ }^{\text {[7] }}$.

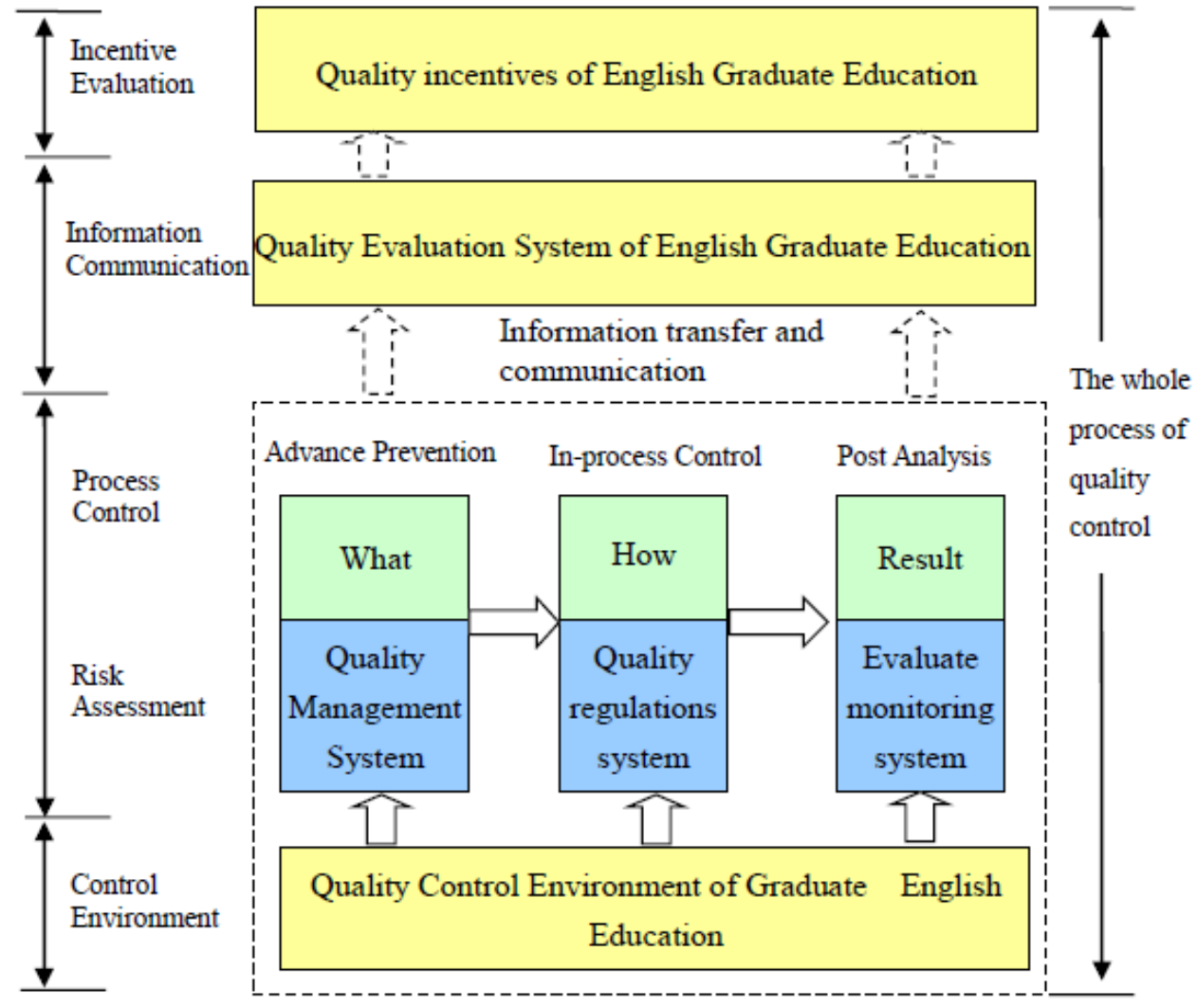

Figure 1 The Whole Process of Quality Control of English Graduate Education

\section{Control Environment------ “Management Atmosphere”}

Control environment provides the college talent training quality control architecture, shapes school culture of talent cultivation quality control, therefore it is the foundation of the other four elements in the internal control framework. In the quality control of English graduate education, the environment factors include: educational philosophy, school culture, teaching conditions, scientific research and academic exchange, which are the preconditions of effective internal control of English graduate education. In the process of management, colleges and universities should construct quality control supporting environment system, pay attention to the school spirit, style of study, class culture, the construction of moral education, to establish a distinctive culture of English graduate student training and create the atmosphere of whole process quality management ${ }^{[8]}$.

\section{Risk Assessment - “manage what”}

With the advancement of deepening the reform of English graduate education, the enlargement of enrollment and the increase of the pressure of competition among colleges and universities, the sound mechanism of risk assessment becomes the key to improving the quality of English graduate education. Universities must know the risks, and make qualitative or quantitative risk assessment to 
the whole process of English graduate student training. Then, based on the results of risk assessment, they take some measures on relevant control activities. In the process of graduate recruitment, these measures should include analyzing the potential risks in enrollment in advance, completing the enrollment plan, ensuring the high quality graduate; while in the process of English graduate education, we should prevent the instructor from laying particular stress on theory away from the practice in the teaching process etc.

\section{Control activities - "How to Manage”}

In English graduate education system, the process of talent training is an important link in the whole system, and one of the important factors affecting the quality of personnel training. And it is also the main object of quality control. Control activities mainly include:

Teaching process control

This teaching process here refers to the process of teaching involved only teacher, including teacher process control, process control, experimental teaching process control, internship teaching process control, professional education, process control, process control of graduation thesis, etc. These goals will be achieved through the evaluation of teacher's teaching, graduation design (paper) subject, opening, guidance, thesis defense and so on.

Learning process control

Students learning process control is to conduct control quality activities related to students learning, including the process control of students record management, the process control of students performance management, the process control of optional courses, classroom learning control and the second classroom learning process control.

Management process control

The key points in management process control are focused on the process control of teaching construction and reform teaching operation management, process control of practicing teaching management, teaching material construction and management process, the teaching quality management process control, etc. Management process control involves every aspects of the whole teaching work.

\section{Information Communication - “Control Process”}

In the process of graduate education, all levels organizations from schools need combine some internal and external information into their daily management activities, and it is necessary to establish a reasonable and effective internal and external information communication mechanism. In internal communication, in order to fully understand the students' ideological trend, collect students' new ideas, give students a way to reflect the problem, and express students' emotion, the flexible tutorial system is implemented in the whole process of the English graduate education under the premise of two-way choice between teachers and students ${ }^{[9]}$. In external communication, the communication with the outside world should be strengthened. Universities should provide more chances to let the students do some internship in the enterprises, and employ more professors outside of campus to come to the classroom.

\section{Supervision --------“How about the Management”}

In the internal control theory, supervision refers to real-time evaluation of the quality of the internal control implementation program, and this program includes continuous supervision or independent evaluation or the combination of these two. In the whole process of English graduate education, universities should supervise and evaluate the students' learning autonomy, initiative, innovative employment ability objectively, which is an important part of quality control system of graduate education. In addition, a comprehensive evaluation of the students' basic quality, adaptability, practical level and development potential must be done through internship employer, employers, students' parents and various social forces. From these evaluation, we get feedback about teaching information to improve the teaching mode and teaching design, and perfect the quality control links, improving the overall effect of English graduate student training. 


\section{Administration Strategies of Quality Control of English Graduate Education, Based on the Theory of Internal Control}

Higher education has entered the stage of popular education in our country, and the competition among colleges and universities gradually intensified. The talent training quality is regarded as the lifeline of survival and development of colleges and universities. Therefore, colleges and universities must put the talents training work in unprecedented heights. In order to strengthen the graduate student quality control, some strategies should be:

The Establishment of Hierarchical and Diversified Evaluation System with Reference to the Talent Training Quality Assurance Experience in the Developed Countries

We should actively learn from lessons and experiences of developed countries to establish quality assurance system, based on Chinese actual situation, properly dealing with the relationship among the scale, quality, and structure. A fair, transparent and authority of graduate education quality evaluation system is made to meet national conditions and the school's facts. One way is to establish a national independent evaluation institution, which evaluate and recognize the universities according to different levels; the other is to encourage different groups of colleges and universities to establish evaluations, which will do paralleled, independent and autonomous evaluation.

\section{Perfect the Rules and Regulations of Teaching Management System and Establish the Quality Standards of Each Main Teaching Link}

School has always regarded the teaching quality of education as the lifeline of survival and development. According to the actual needs of the modern education concept and teaching management, a set of scientific, standardized and practical teaching system is formed, and a timely revision and perfect management system follow. And at the same time, quality standards of professional construction, curriculum construction quality standards and classroom teaching quality standards, and a series of standards system should be made. Thus, all of these can provide institutional guarantee for the improvement of the teaching quality monitoring system. With the system of teaching management, universities should take effective measures to strictly implement the talent training scheme and standardize teaching process to ensure the implementation of the teaching management system.

\section{Establish and Improve the Teaching Quality Monitoring and Security System, Strengthens the Organic Integration of Process Management And Objective Management}

First of all we need to improve the teaching quality monitoring organization structure, implementing the supervision and inspection in three levels of school, school (department) and teaching and research section. Moreover, universities must strengthen the risk consciousness, making full use of information technology to strengthen the teaching management organization and command system, information collection system, teaching quality evaluation system, and teaching information feedback and regulation rules and construction of the system. In addition, leaders the teaching supervisors should listen to graduates classes. Students evaluating teachers, and teaching inspection and other forms of teaching quality evaluation and the monitoring should be used to realize the combination of process management and objective management.

\section{Build a Multi-Level Experiment Teaching System, And Construct Practice Teaching Textbook Series}

To achieve inter-disciplinary talent training goal, "an Omni-directional, multilevel and information sharing” experimental teaching system should be employed. This system will strengthen experiment links and construct new experimental teaching mode with professional characteristics. First of all, an information sharing experimental environment is needed. Then universities should equipped with various kinds of database technology equipment as well as experimental database meeting the needs of the experimental teaching experiments. What's more, 
there must be a series of rules and regulations on teaching outline, teaching method, examination evaluation index system, etc. Finally, according to professional practice, some practice teaching textbook series should follow.

\section{Innovative Talents Training Mode, Improve Evaluation System Focusing on the Ability}

The national medium and long-term education reform and development plan outline (2010-2020) noted that higher education should "support the student to participate in scientific research, strengthen the practice teaching link, and promote the scientific research and teaching interaction, combined with innovative talent training”. Graduate education is to emphasize quality-oriented education and ability training as the basic orientation and training target. This request should cultivate the students' analysis ability and application ability as the center in the process of graduate education. According to the requirements for the talents cultivation target, universities need innovative talents training mode, cultivating students' ability to learn autonomously, find the problems, and to analyze and solve problems. This mode will realize the combination of process management and objective management [10].

\section{Summary}

To meet the needs of management talent in social and economic development, universities undertake the task of the graduate administration and personnel training. According to the characteristics of higher education of finance and economics, through the reform and construction of the project of talent training plan, internationalization of education mode, innovative teaching mode, universities cultivate high-quality English personnel who meet the social needs of the development.

\section{Acknowledgements}

Fund project: Shandong social science planning research project (project number: 11dkjj07); Education Reform Project of Shandong Institute of Business and Technology in 2015(project number: 11688JXYJ2015035)

\section{Reference:}

[1]Chenping, Chencheng. Based on the theory of internal control, MPACC training quality guarantee system [J].Business Accounting, 2014, (07): 13-16.

[2]Chenping, Duanyingying. Based on the COSO internal control framework of MPACC quality security system research [J]. Graduate education research, 2014, (05) :73-78.

[3]Songshuqin.Based on the internal control framework of talent training quality guarantee and evaluation system of research [J]. Journal of human institute of finance and economy, 2012, 28(139): 73-78.

[4]Devingrant. Quality management in US higher education [J]. Total Quality Management, 2002,(2):207-209.

[5]Hanhongling, Guoyanmin, Chenhanwen. The applicability of supervision and internal control elements for development - based on risk theory model and its reference guide [J]. Accounting research, 2009, (8):73-79.

[6]Chenzhiwen. Education from departments of college teaching quality guarantee system construction guide[M].Beijing: China’s education press, 2010.

[7]Zhangyan. To improve the quality of talent cultivation in colleges and universities four key management link [J].Journal of Anshan normal college, 2008, (6): 104-105. 
[8]Fangguiting. Stick to the needs of society, promote the reform of postgraduate training mode, in the reform of the wuhan university, for example [J]. Journal of hubei normal university (philosophy and social sciences edition), 2009, 29(01):122-124.

[9]Zhuxueyi. Based on the academic master's top creative talents cultivation of research capacity [J].Graduate education research, 2012, (04):50-53.

[10]Gezhibo. The graduate student course management thinking [J].Heilongjiang province higher education research, 2002,(02):83-85. 